graft survival of skin in pregnant women (Andresen and Monroe, 1962). Our findings further indicate that this reduction in $\mathrm{T}$-cell response in pregnancy is no longer obvious seven days after delivery.

Our observation that the depressed maternal lymphocyte response to PHA returned to normal after washing the cells and removing autologous plasma from the culture provides direct evidence of an inhibitory factor in the mother's own plasma. Seven days after delivery, however, the effect of the inhibitor was not apparent. Pregnant sera may suppress the PHA response of normal adult lymphocytes (Walker et al., 1972; St Hill et al., 1973; Leikin, 1972). Various hormones, including corticosteroids (Whitfield et al., 1968), progesterone (Munroe, 1971), oestrogen (Waltman et al., 1971), and chorionic gonadotrophin (Kaye and Jones, 1971), show immunosuppressive properties. Depressed lymphocyte response to PHA in women taking oral contraceptives also suggests a nonspecific oestrogen or progesterone action (Hagan and Forland, 1972; Fitzgerald et al., 1973; Barnes, 1974). Carcinoembryonic antigen (Gold, 1967), $\alpha$-globulin (Cooperband et al., 1968), placental glycoprotein (Riggio et al., 1971), and $\alpha$-fetal protein (Purves and Geddes, 1972) have also exhibited immunosuppressive properties.

Spontaneous blast transformation of cord-blood lymphocytes in control cultures without PHA has been reported to be higher (Leikin et al., 1968; Pulvertaft and Pulvertaft, 1966), similar to (Jones, 1969), and less than (Lindahl-Kiessling and Böök, 1964) that of adult lymphocytes. Recent studies of DNA synthesis with radioactive tagging showed significantly higher background counts for unstimulated cells in cord-blood samples than for adult control cells (Montgomery et al., 1973) and our present and earlier observations (Campbell et al., 1974) also confirmed this.

Reports on the mitotic response of cord-blood lymphocytes to PHA are also conflicting. Some workers found their PHA response lower than that of adult lymphocytes (Jones, 1969; Montgomery et al., 1973; Ayoub and Kasakura, 1971), and others have shown them to parallel that of adult cells (Leikin et al., 1968; Meuwissen et al., 1968). Others showed that the response of cord-blood lymphocytes was higher than that of adult control lymphocytes (Lindalh-Kiessling and Böök, 1964; Campbell et al., 1974). Our results confirm these latter reports but only when the cells were cultured with autologous plasma removed. This inhibitory effect of newborn plasma on the infants' own cells was not obvious seven days after birth. Fetal sera suppress the PHA response of normal adult lymphocytes
(Ayonb and Kasakura, 1971) and it was postulated that separate molecules were responsible for the inhibitory effect in maternal and fetal sera (Kasakura, 1971). A recent study, however, suggested that fetal serum has a greater depressive action than maternal serum and hence the inhibitor may be derived from the fetal-placental unit (St Hill et al., 1973). The nature of the inhibitory factor is unknown and further studies are required to clarify its nature and source of this plasma inhibitory factoras well as its role in the survival of the fetal allograft in human pregnancy.

\section{References}

Andreson, R. H., and Monroe, C. W. (1962). American fournal of Obstetrics and Gynecology, 84, 1096.

Ayoub, J., and Kasakura, S. (1971). Clinical and Experimental Immunology, $8,427$.

Barnes, E. W., et al. (1974). Lancet 1, 898.

Bloom, B. R. (1971). Advances in Immunology, 13, 101.

Campbell A. C., et al. (1975). Clinical and Experimental Immunology. In Press.

Cooperbar., S. R, et al (1968), Science, 159, 1243.

Craig, A. W., Garrett, J. V., and Jackson, S. M. (1969). fournal of Clinical Pathology, 22, 558. . British Medical fournal, 3, 150. Finn, R., et al. (1972). British Medical fournal, 3, 150.
Fitzgerald, P. H., Pickering, A. F., and Ferguson, D. N. (1973). Lancet, 1, 615

Gole, P. (1967). Cancer, 20, 1663.

Hager, C., and Froland, A. (1972). Lancet, 1, 1185

Jones, W. R. (1969). American fournal of Obstetrics and Gynecology, 104, 586.

Kaye, M. D., and Jones, W. R. (1971). American fournal of Obstetrics and Gynecology, 109, 1029.

Kasakura, S. (1971). Fournal of Immunology, 107, 1296.

Leikin, S. (1972). Lancet, 2, 43.

Lekin, S., Mochir-Fatemi, F., and Park, K. (1968). Fournal of Pediatrics, $72,510$.

Lindahl-Kiessling, K., and Böök, J. A. (1964). Lancet, 2, 591.

Maini, R. N., et al. (1973). Proceedings of the 8th Leucocyte Culture Conference, Üppsala.

ference, Uppsala.
Meuwissen, $\mathrm{H}$. j., et al. (1968). Fournal of Pediatrics, 72, 177.

Meuwissen, H. J., et al. (1968). Fournal of Pediatrics, 72, 177.
Montgomery, J. R., Mason, E. O., and South, M. A. (1973). Pediatric Research, 7,365 .

Munroe J. S. (1971). Fournal of Reticuloendothelial Society, 9, 361.

Phillips, B., and Weisrose, E. (1974). Clinical and Experin ental Immunology, 16,383 .

Pulvertaft, R. J. V., and Pulvertaft, I. (1966). Lancet, 2, 892

Purtilo, D. T., Hallgren, H. M., and Yunis, E. J. (1972). Lancet, 1, 769.

Purves, L. R., and Geddes, E. W. (1972). Lancet, 1, 47.

Riggio, R. R., et ul. (1971). Transplantation, 12, 400.

Smith, J. K., Caspary, E. A., and Field, E. J. (1972). Lancet, 1, 96.

St Hill, C. A., Finn, R., and Denye, V. (1973). British Medical fournal, 3,

513.
Walker, J. S., Freeman, C. B., and Harris, R. (1972). British Medical fournal 3,169 .

Waltman, S. R., Burde, R. M., and Berrios, J. (1971). Transplantation, 11, 194.

Whitfield, J. F., Perris, A. D., and Youdale, T. (1968). Experimental Cell Research, 52, 349.

\title{
Comparison of Aerosol Ipratropium Bromide and Salbutamol in Chronic Bronchitis and Asthma
}

\author{
G. R. PETRIE, K. N. V. PALMER
}

British Medical fournal, 1975, 1, 430-432

\section{Summary}

The effects of inhaling $200 \mu \mathrm{g}$ of salbutamol were compared with those of inhaling $40 \mu \mathrm{g}$ of ipratropium bromide singly and in combination with salbutamol in

University Department of Medicine, Foresthill, Aberdeen AB9 2ZD G. R. PETRIE, M.B., M.R.C.P., Research Fellow

K. N. V. PALMER, M.B., F.R.C.P., Reader in Medicine eight patients with bronchitis and eight asthmatic patients in a double-blind controlled trial. Changes in airways resistance were assessed by measuring the forced expiratory volume in 1 second and specific airways conductance. Both drugs were significantly better in relieving airways obstruction than placebo. Salbutamol was significantly more effective than ipratropium bromide in patients with asthma, but in the patients with bronchitis there was no significant difference between salbutamol and ipratropium bromide. The combination of the two drugs produced a slightly greater and longer response than either drug alone but this was not significant. 


\section{Introduction}

A bronchodilator effect to anticholinergic drugs such as atropine is commonly seen in bronchitic patients, and whereas asthmatic patients respond poorly to atropine they respond better to adrenergic receptor stimulant drugs such as isoprenaline (Crompton, 1968; Altounyan, 1964). In patients with chronic bronchitis inhalation of $40 \mu \mathrm{g}$ of the new anticholinergic drug ipratropium bromide (Sch 1000, Boehringer Ingleheim) produced stronger and more persistent bronchodilation than the inhalation of $200 \mu \mathrm{g}$ of salbutamol (Poppius and Salorinne, 1973). This difference in response to anticholinergic drugs between bronchitis and asthma has been used to distinguish between allergic and non-allergic airways obstruction (Altounyan, 1966). We compared the effect of inhalation of ipratropium bromide with salbutamol in asthmatic and bronchitic patients in a placebo-controlled study.

\section{Patients and Methods}

Eight men with ohronic bronchitis and eight patients with chronic asthma were studied (table I). All gave their informed consent, and women of child-bearing age were excluded. None of the bronchitic patients had sputum or blood eosinophilia whereas all the asthmatic patients did. The bronchitic patients were or had been cigarette smokers, but none of the asthmatic patients smoked. The clinical diagnosis of bronchitis was based on the Medical Research Council's quest:onnaire on respiratory symptoms (Medica! Research Council, 1965) and that of asthma was based on criteria la:d down at the Ciba Foundation Symposium (1971). No patient had received corticosteroids or sodium cromoglycate, and bronchodilators or other therapy were discontinued for 12 hours before each experiment. The patients visited the laboratory on four consecutive days at 9.00 a.m. to exclude the effect of diurnal varation in ventilatory function. Each day baseline measurements of the forced exp:ratory volume in 1 second $\left(\mathrm{FEV}_{1}\right)$ and specific airways conductance (SGaw) were made. The $\mathrm{FEV}_{1}$ was recorded in millilitres (ambient temperature and pressure saturated with water vapour (ATPS)) from the best of three spirograms obtained with a drywedge spirometer. Airways resistance (Raw) and thoracic gas volume were measured simultaneously in a constant-volume body plethysmograph and the results were expressed as a specific airways conductance (SGaw), which is the reciprocal of airways resistance per litre of thoracic gas volume. SGaw was expressed in $\mathrm{ml} \mathrm{s} \mathrm{kPa}^{-1} 1^{-1}(\mathrm{ml} / \mathrm{sec} / \mathrm{cm} \mathrm{H}, \mathrm{O} / 1 \times 10)$ and each reading was the mean of three determinations.

TABLE I-Mean Values (and Ranges) for Age Height Weight and Spirometry for Asthmatic and Bronchitic Patients

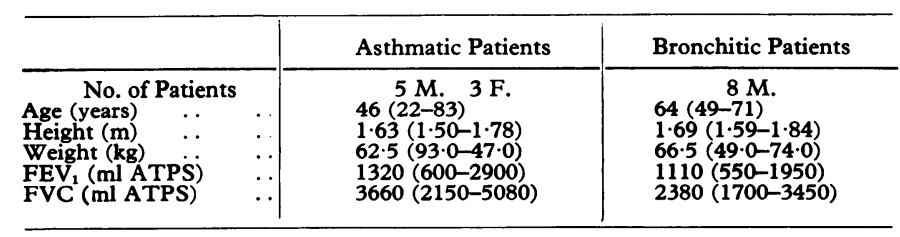

For statistical analysis the logarithms of SGaw were used since the distribution of this measurement is log normal, or skewed (Guyatt and Alpers, 1968). After baseline measurements, which were all stable, ipratropium bromide $40 \mu \mathrm{g}$ and placebo, salbutamol $200 \mu \mathrm{g}$ and placebo, ipratropium bromide $40 \mu \mathrm{g}$ and salbutamol $200 \mu \mathrm{g}$, or placebo and placebo inhalations were given from identical aerosol canisters in balanced randomized order. The effects of the drugs on $\mathrm{FEV}_{1}, \mathrm{SGaw}$, pulse rate, and blood pressure were measured at $15,30,60,120,180$, and 240 minutes after the drug.
On a separate occasion the response to atropine followed by isoprenaline was measured. The basal $\mathrm{FEV}_{1}$ was measured and measured again one hour after the aerosol inhalation of $0.2 \%$ atropine methonitrate from a Collison inhaler operating at a flow rate from a cylinder containing air at $81 / \mathrm{min}$. Five minutes later $1 \%$ aqueous isoprenaline was given in a similar way and the $\mathrm{FEV}_{1}$ was measured. The percentage atropine response was expressed as

$$
\left(\frac{\text { rise in } \mathrm{FEV}_{1}(\mathrm{ml}) \text { after atropine }}{\text { rise in } \mathrm{FEV}_{1}(\mathrm{ml}) \text { after isoprenaline }}\right) \times 100
$$

Patients who have an atropine response of greater than $75 \%$ are more likely to have non-allergic airways obstruction (Altounyan, 1964).

\section{Results}

The rise in mean $\mathrm{FEV}_{1}$ from the basal level for the asthmatic and bronchitic patients with the various combination of aerosols is shown in table II, and in SGaw in table III. Statistically the

TABLE II-Rise in Mean FEV from Basal Reading (ml ATPS) in Asthmatic $(A)$ and Bronchitic $(B)$ Patients

\begin{tabular}{|c|c|c|c|c|c|c|c|c|}
\hline \multirow[t]{2}{*}{ Time (min) } & \multicolumn{2}{|c|}{$\begin{array}{l}\text { Ipratropium } \\
\text { Bromide } \\
\text { and } \\
\text { Salbutamol }\end{array}$} & \multicolumn{2}{|c|}{$\begin{array}{l}\text { Placebo } \\
\text { and } \\
\text { Placebo }\end{array}$} & \multicolumn{2}{|c|}{$\begin{array}{c}\text { Ipratropium } \\
\text { Bromide } \\
\text { and } \\
\text { Placebo }\end{array}$} & \multicolumn{2}{|c|}{$\begin{array}{c}\text { Salbutamol } \\
\text { and } \\
\text { Placebo }\end{array}$} \\
\hline & A & B & A & B & A & B & A & B \\
\hline $\begin{array}{r}\text { Basal } \\
15 \\
30 \\
60 \\
120 \\
180 \\
240\end{array}$ & $\begin{array}{r}1100 \\
552 \\
605 \\
685 \\
620 \\
543 \\
483\end{array}$ & $\begin{array}{r}1140 \\
192 \\
177 \\
197 \\
197 \\
224 \\
174\end{array}$ & $\begin{array}{r}1028 \\
48 \\
-2 \\
43 \\
143 \\
178 \\
86\end{array}$ & $\begin{array}{r}1078 \\
31 \\
42 \\
20 \\
37 \\
1 \\
10\end{array}$ & $\begin{array}{r}1040 \\
148 \\
180 \\
300 \\
328 \\
312 \\
317\end{array}$ & $\begin{array}{r}1116 \\
86 \\
89 \\
149 \\
165 \\
169 \\
90\end{array}$ & $\begin{array}{l}983 \\
657 \\
670 \\
695 \\
652 \\
497 \\
448\end{array}$ & $\begin{array}{r}1115 \\
151 \\
157 \\
195 \\
151 \\
159 \\
116\end{array}$ \\
\hline
\end{tabular}

TABLE III-Rise in Mean SGaw $\left(m l s^{-1} \mathrm{kPa}^{-1} l^{-1}\right)^{*}$ in Asthmatic $(A)$ and Bronchitic (B) Patients

\begin{tabular}{|c|c|c|c|c|c|c|c|c|}
\hline \multirow[t]{2}{*}{ Time (min) } & \multicolumn{2}{|c|}{$\begin{array}{c}\text { Ipratropium } \\
\text { Bromide } \\
\text { and } \\
\text { Salbutamol }\end{array}$} & \multicolumn{2}{|c|}{$\begin{array}{l}\text { Placebo } \\
\text { and } \\
\text { Placebo }\end{array}$} & \multicolumn{2}{|c|}{$\begin{array}{c}\text { Ipratropium } \\
\text { Bromide } \\
\text { and } \\
\text { Placebo }\end{array}$} & \multicolumn{2}{|c|}{$\begin{array}{c}\text { Salbutamol } \\
\text { and } \\
\text { Placebo }\end{array}$} \\
\hline & A & B & A & B & A & B & $\mathbf{A}$ & B \\
\hline $\begin{array}{c}\text { Basal } \\
15 \\
30 \\
60 \\
120 \\
180 \\
240\end{array}$ & $\begin{array}{l}218 \\
449 \\
354 \\
433 \\
313 \\
129 \\
154\end{array}$ & $\begin{array}{l}352 \\
169 \\
227 \\
174 \\
187 \\
185 \\
216\end{array}$ & $\begin{array}{c}219 \\
-15 \\
-053 \\
045 \\
18 \\
-11 \\
-20\end{array}$ & $\begin{array}{r}308 \\
16 \\
15 \\
16 \\
46 \\
41 \\
11\end{array}$ & $\begin{array}{r}236 \\
93 \\
90 \\
124 \\
65 \\
73 \\
35\end{array}$ & $\begin{array}{l}296 \\
167 \\
179 \\
201 \\
202 \\
161 \\
185\end{array}$ & $\begin{array}{r}180 \\
256 \\
269 \\
259 \\
163 \\
125 \\
85\end{array}$ & $\begin{array}{l}316 \\
183 \\
193 \\
186 \\
215 \\
153 \\
127\end{array}$ \\
\hline
\end{tabular}

* Normal range for SGaw $1140-4140 \mathrm{ml} \mathrm{s}^{-1} \mathrm{kPa}^{-1} \mathrm{l}^{1}$ (114-414 ml/sec/cm $\left.\mathrm{H}_{2} \mathrm{O} / \mathrm{l}\right)$.

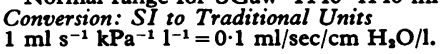

mean improvement was assessed by subtracting the predrug reading from the average of six readings after the inhalations, the changes on placebo being substracted from these results. The changes with the drug combinations are shown in table IV. Both drugs were much more effective than placebo, especially in patients with asthma, as the mean values were several times greater than the standard errors. Salbutamol was significantly better than ipratropium bromide $(P<0.05)$ in asthmatic patients whether $\mathrm{FEV}_{1}$ or $\log \mathrm{SGaw}$ was used as the criterion. The bronchitic patients showed a slightly greater rise in mean

TABLE IV-Mean Changes ( ${ }^{ \pm}$S.E.) in FEV 1 and Log SGaw over 240 Minutes after Drugs or Placebo compared with Baseline Measurements in Asthmatic (A) and Bronchitic $(B)$ Patients

\begin{tabular}{|c|c|c|c|c|c|c|c|c|}
\hline & \multicolumn{2}{|c|}{ Placebo and Placebo } & \multicolumn{2}{|c|}{ Salbutamol and Placebo } & \multicolumn{2}{|c|}{$\begin{array}{l}\text { Ipratropium Bromide } \\
\text { and Placebo }\end{array}$} & \multicolumn{2}{|c|}{$\begin{array}{c}\text { Ipratropium Bromide } \\
\text { and Salbutamol }\end{array}$} \\
\hline & A & B & A & B & A & B & $\mathbf{A}$ & B \\
\hline $\begin{array}{l}\mathrm{FEV}_{1} \text { (ml ATPS) } \\
\log _{\mathrm{SPa}^{-1}\left(\mathrm{G}^{-1}\right)}\left(\mathrm{ml} \mathrm{s}^{-1}\right.\end{array}$ & $\begin{array}{c}40 \pm 40 \\
-0.30 \pm 0.90\end{array}$ & $\begin{array}{c}20 \pm 40 \\
0.50 \pm 0.50\end{array}$ & $\begin{array}{l}560 \pm 160 \\
6 \cdot 70 \pm 1 \cdot 0\end{array}$ & $\begin{array}{l}150 \pm 60 \\
4 \cdot 7 \pm 1 \cdot 2\end{array}$ & $\begin{array}{r}290 \pm 100 \\
4 \cdot 0 \pm 1 \cdot 2\end{array}$ & $\begin{array}{l}130 \pm 40 \\
4 \cdot 3 \pm 1 \cdot 0\end{array}$ & $\begin{array}{l}580 \pm 60 \\
9 \cdot 6 \pm 1 \cdot 8\end{array}$ & $\begin{array}{l}190 \pm 130 \\
5 \cdot 1 \pm 1 \cdot 5\end{array}$ \\
\hline
\end{tabular}


SGaw after ipratropium bromide than after salbutamol but the difference was not significant. The combination of the two drugs produced a slightly greater and longer response than either alone, but the effect was not significant. Neither drug has any more effect on pulse rate or blood pressure than placebo. The mean results of the atropine tests differed significantly between the bronchitic $(85.4 \%)$ and the asthmatic groups $(47.4 \%$; $P<0.01$ ).

\section{Discussion}

These results show that both salbutamol and ipratropium bromide have a pharmacological bronchodilator action in asthmatic and bronchitic patients. The effect of salbutamol is significantly greater in asthmatic patients, however, than in bronchitic patients. In asthmatic subjects Lahdensuo et al. (1973) found a larger mean increase in peak expiratory flow after salbutamol than after ipratropium bromide. In spite of the fact that the atropine test clearly separated the asthmatic and bronchitic patients, suggesting that bronchitics respond better to anticholinergic than to beta-adrenergic stimulant drugs, there was no significant difference in the responses of the bronchitic patients to either drug. This may be because bronchitic patients respond less well to bronchodilator drugs in general, and therefore differences in response are harder to prove. Possibly the two drugs might be effective in different patients but since the response to ipratropium bromide and salbutamol was highly correlated this did not seem to be the case. The atropine test separated well patients with non-allergic and allergic airway obstruction. It did not give an indication, however, of the individual response of the patient to the drugs. The combination of the two drugs produced a slightly greater and more prclonged response than either alone.

In conclusion, in asthma salbutamol aerosol is more effective than ipratropium bromide whereas both drugs have a comparable bronchodilation effect in bronchitics.

We thank Professor David Kerridge for statistical advice and Boehringer Ingleheim Ltd. for supplying ipratropium bromide.

Requests for reprints should be addressed to Dr. K. N. V. Palmer, University Department of Medicine, Foresterhill, Aberdeen AB9 2ZD.

\section{References}

Altounyan, R. E. C. (1964). Thorax, 19, 406.

Altounyan, R. E. C. (1966). Proceedings of the Royal Society of Medicine,

59, Suppl., p. 56.

Crompton, G. K. (1968). Thorax, 23, 46 .

Guyatt, A. R., and Alpers, J. H. (1968). Fournal of Applied Physiology, 24, 310

Lahdensuo, A., Viljanen, A. A., and Muittari, A. (1973). Scandinavian fournal of Clinical and Laboratory Investigation, 31, Suppl No. 130, 16. Medical Research Council (1965). Lancet, 1, 775.

Poppius, H., and Salorinne, Y. (1973). British Medical fournal, 4, 134.

\title{
Depression of Bone Marrow Colony Formation in Gold-induced Neutropenia
}

\author{
A. HOWELL, J. M. GUMPEL, R. W. E. WATTS
}

British Medical fournal, 1975, 1, 432-434

\section{Summary}

Bone marrow culture in semi-solid agar was used to assess the proliferative activity and the response to sodium aurothiomalate of the myeloid precursor cells from patients during and after recovery from neutropenia associated with the use of this drug. Colony formation was reduced during the neutropenia and returned to normal after recovery. The rheumatoid process itself did not impair colony formation even in patients with Felty's syndrome. Sodium aurothiomalate inhibited colony formation by normal marrow in a dosedependent manner. Bone marrow colonies from patients who had recovered from neutropenia induced by sodium aurothiomalate were not abnormally sensitive to the inhibitory effect of the drug in vitro. The metabolism of gold is probably altered in a small proportion of patients, which causes high local concentrations within the bone marrow leading directly to marrow depression.

\footnotetext{
Division of Inherited Metabolic Diseases, M.R.C. Clinical Research Centre, Northwick Park Hospital, Middlesex HA1 3UJ

A. HOWELL, M.B., M.R.C.P., Member of Scientific Staff
}

R. W. E. WATTS, M.D., F.R.C.P., Head of Division

Rheumatology Unit, Northwick Park Hospital, Middlesex HA1 3UJ J. M. GUMPEL, B.M., M.R.C.P., Consultant Physician

\section{Introduction}

Idiosyncratic agranulocytosis and neutropenia may be caused by a variety of therapeutic agents, and from the limited data on the mechanism of agranulocytosis Pisciotta (1973) proposed a classification into two types. Type I, best exemplified by amidopyrine sensitivity, occurs shortly after ingestion of a little drug in a patient sensitized by its previous administration and causes a precipitous decline in the neutrophil count. Leucoagglutinins are found, there is immunological destruction of peripheral neutrophils. Type II reactions differ: they occur during continuous treatment with a drug and are associated with bone marrow depression and interference with granulocyte production. Reintroduction of the drug after recovery does not cause immediate decline of neutrophils. Pisciotta (1973) suggested that this type of agranulocytosis is secondary to a specific biochemical defect in the patient and is best exemplified by chlorpromazine sensitivity, and he has shown that the bone marrow of patients who have recovered from chlorpromazine sensitivity incorporates radioactive precursors into nucleic acids more slowly than control marrow. Colony formation in the agar culture system is decreased and more of the cells are in the $G_{1}$ phase of the cell cycle. He suggests that treatment with chlorpromazine in patients with inherently reduced marrow proliferation results in agranulocytosis.

Bone marrow depression is an uncommon but a serious side effect of gold therapy for rheumatoid arthritis. In one series $27 \%$ of 55 cases of thrombocytopenia, neutropenia, or aplastic anaemia caused by gold salts were fatal (Kay, 1973). Goldinduced neutropenia has many features of a type II reaction: it occurs usually after weeks of therapy with a slow decline of neutrophil numbers, and therapy can often be continued after 